\title{
PEDAGOGICAL CONDITIONS OF TEACHING FOREIGN LANGUAGES OF STUDENTS IN SECONDARY AND HIGH PEDAGOGICAL EDUCATIONAL ESTABLISHMENTS: PAST AND PRESENT
}

\section{ПЕДАГОГІЧНІ УМОВИ ВИКЛАДАННЯ ІНОЗЕМНИХ МОВ УЧНІВ У СЕРЕДНІХ І ВИЩИХ ПЕДАГОГІЧНИХ НАВЧАЛЬНИХ ЗАКЛАДАХ: МИНУЛЕ ТА СЬОГОДЕННЯ}

The article deals with the pedagogical conditions of teaching foreign languages in the pedagogical schools and pedagogical educational establishments of Ukraine in the second half of the twentieth century and modern ones. It is proved that the studied historical period was rich in historical events that influenced the search and creation of new methods of teaching foreign language of young people, generalization and systematization of the existing achievements of scientists, teachers, methodologists and linguists. We described the features of methods for development of foreign language skills in accordance with the selected stages of teaching foreign languages. The teaching of foreign languages in the modern world is an integral part of the professional training of specialists. Foreign language training begins at the kindergarten and continues in other types of educational institutions. The level of foreign language which the student receives at school is decisive, because it containsis skills of foreign language activities (listening, speaking, reading, writing). The effectiveness depends on the methodology of the teacher and his ability to use modern methods in the context of solving the educational tasks of foreign language training of young people. Today in Ukraine there are changes in the system of preparation of teachers of foreign languages, the improvement of the skills of teachers, the introduction of international standards for the assessment of foreign language knowledge, the implementation of new approaches and methods. On the basis of the analysis of scientific and pedagogical literature, the definition of the concept of "pedagogical conditions" was collected by Ukrainian and foreign scholars. We distinguish general and special pedagogical conditions of teaching foreign languages. The general pedagogical conditions that are based on the principles of the pedagogical process include: the purposefulness of the pedagogical process, the scientific content of education and education, the systematic and consistency, consciousness, activity, the creativity of students in the pedagogical process, the choice of optimal methods, forms, means of education and education, and others. Special pedagogical conditions include the conditions necessary for acquiring knowledge and skills from individual subjects, taking into account the peculiarities of their learning.

Key words: education, educational institutions, foreign languages, foreign language training, pedagogical aspects, pedagogical conditions, skills, students, studying, teaching.
У статті розглядаються педагогічні умови навчання іноземних мов у педагогічних училищах другої половини $X X \mathrm{~cm}$. та у сучасних закладах педагогічної освіти України. Доведено, що досліджуваний історичний період був багатим на історичні події, які вплинули на пошук і створення нових методів навчання молоді іноземної мови, узагальнення та систематизацію досягнень вчених, викладачів, методистів і лінгвістів. Описано особливості розвитку методів навчання іноземної мови відповідно до періодів іншомовної підготовки студентів закладів педагогічної освіти. Викладання іноземних мов у сучасному світі є невід'ємною частиною професійної підготовки орахів чів. Навчання іноземної мови починається в дитячому садку і продовжується в інших типах навчальних закладів. Рівень іноземної мови, який студент отримує у школі, $є$ визначальним, оскільки містить навички іншомовної діяльності (слухання, говоріння, читання, письмо). Ефективність залежить від методики викладача та його вміння використовувати сучасні методи в контексті вирішення навчальних завдань з іноземної мови. Сьогодні в Україні відбуваються зміни в системі підготовки вчителів іноземних мов, підвищення кваліфрікації викладачів, впровадження міжнародних стандартів оцінювання знань з іноземної мови, впровадження нових підходів і методів.

На основі аналізу науково-педагогічної літератури було визначено складові частини поняття «педагогічні умови» в контексті навчання іноземних мов: загальні та спеціальні педагогічні умови. До загальних педагогічних умов, що грунтуються на принципах педагогічного процесу, належать: цілеспрямованість педагогічного процесу, науковість змісту навчання та виховання, систематичність і послідовність, свідомість, активність, творчість студентів у педагогічному процесі, вибір оптимальних методів, форм, засобів навчання та виховання та ін. До спеціальних педагогічних умов належать умови, необхідні для набуття знань і вмінь з окремих предметів з урахуванням особливостей їх навчання.

Ключові слова: освіта, навчальні заклади, іноземні мови, навчання іноземної мови, педагогічні аспекти, педагогічні умови, навички, студенти, навчання, викладання.
The relevance ofthe problems. Development of Ukraine as an independent state has become a prerequisite for changes in public life, led to the emergence of the new reforms in teacher education with a focus on the preservation and enhancement of accumulated in the Soviet time experience while making significant changes in objectives, content and objectives of the educational process. In the educational policy of Ukraine two major trends were determined: the first is the revival of national consciousness, culture and language, the second is the focus on the European and world community, which requires the mandatory practical knowledge of foreign languages. Language is the opportunity to reflect historical and cultural traditions and peculiarities of their own people, to find common and distinctive traits of every cul- 
ture. The main task of the state is to prepare highly qualified specialists who knows one or more foreign languages. Educational reforms contributed to the emergence of new teaching methods for the development of comprehensively-developed and creative personality, changed the authoritarian style of educational activity on a humanistic approach taking into account the individual characteristics of the young generation. Foreign language is now a tool of intercultural communication, that is why the mastery of foreign language speech activity is not only aimed at development of communicative competence (language, speech, sociocultural, cross-cultural etc.), but also education by means of foreign language.

The purpose ofthe publication: to analyze anddescribe pedagogical conditions in pedagogical educational establishments of Ukraine in the past and present.

Analysis of recent researches and publications. The main educational task of the country is to train highly skilled professionals who know one or more foreign languages. Educational reforms contributed to the emergence of new teaching methods for the development of a fully developed and creative personality, the change of the authoritarian style of educational activity into a humanistic approach, taking into account the individual characteristics of young people. The problem of teaching foreign languages in secondary educational establishments in the second part of the XXth century was described by V.M. Alexander, I.L. Bim, N.D. Galskova, I.O. Georgian, V.D. Arakin, A. Lyubarskaya, N.V. Borisova, O.O. Mirolyubov, A.V. Monighetti, O.I. Moskalskaya, Y.I. Passov, I.V. Rakhmanov, T.V. Litnova, V.S. Cetlin, N.I. Tennova, L.V. Scherba, R.P. Milrod, G.V. Rogova, I.M. Vereshchagina, A.V. Shtifurak, T.M. Shkvarina and others.

Ukraine's national education system was formed in the 1990s in the context of changing political, economic and cultural life of society. The reforms were aimed to creating a new education system in Ukraine while preserving the achievements of Soviet teachers, methodologists, and linguists. These changes are envisaged by the main provisions of the legislative and regulatory documents, the main ones are: the Constitution of Ukraine, the Law of Ukraine "On Education" (1991; 2017), the Law of Ukraine "On General Secondary Education", and the Law of Ukraine "On Higher Education" (2002; 2014), The State National Program "Education" ("Ukraine of the 21st Century") (1993), the State Educational Standard for Foreign Language (1998) and others. They identify the main directions of modernization of the content and methods of education and upbringing of the younger generation. Changes in the teaching of foreign languages in educational institutions of modern Ukraine in the context of the Common European Recommendations as for Language Education are of great importance. In this regard, the direction of reforming teaching foreign languages with the improvement of methods and pedagogy of the second half of the last century has been determined. Theoretical foundations of teaching foreign languages were formed (purpose, objectives, methods); the teaching methods were improved; the goals of teaching foreign language activities were reformed (from the development of reading and translation skills in 1950-1960s, the transition to productive mastery of foreign language in 1970-1980s, the formation of foreign language communication competence in 1990-2000s), personal communicative and differentiated approaches were actively implemented. In addition, according to the results of our study, the improvement of methods and forms of teaching foreign languages of students of secondary pedagogical educational establishments of Ukraine was in accordance with the increasing requirements for the quality of education and upbringing of young people.

The urgent tasks of modern education in the context of European integration processes are the essential updating of the content of education, the search, creation and application of effective forms and methods of teaching to ensure the high quality of knowledge of young people. Priority directions of the state language education are its continuity in order to ensure compulsory mastering of the Ukrainian language by the citizens of Ukraine and practical mastering of foreign language in order to develop a high linguistic culture of citizens, to cultivate tolerance to speakers of European and world languages and cultures, to increase the level of European languages standards. That is why the aim of the article is to learn pedagogical experience of teaching foreign languages in the institutions of secondary special pedagogical education of the second half of the last century, generalization of which will help to find effective methods of teaching foreign languages of young people in modern educational institutions of Ukraine.

We consider the pedagogical conditions of teaching as circumstances or factors of the pedagogical process which help to ensure the effective formation of knowledge and skills in accordance with the program requirements of a certain type of educational institution. We define pedagogical conditions of teaching foreign languages as a complex of organizational and pedagogical factors for the formation of foreign language competence.

On the analysis of historical sources, methodological and scientific literature as for teaching foreign languages in pedagogical institutions of Ukraine, in our opinion, it is advisable to distinguish the following pedagogical conditions of teaching foreign languages as general and special (organizational and pedagogical, qualificational, the complexity of the direction of teaching foreign language activities. General pedagogical conditions are the conditions necessary to ensure the effectiveness of education and training. They are based on the principles of the pedagogical process, such as: purposefulness; scientific content 
of education and upbringing; systematicity and consistency; students' consciousness, activity, creativity; choice of optimal methods, forms, means of training and education; integrated approach to training and education; taking into account the age and individual characteristics of students; strength, awareness and effectiveness of learning outcomes; respect for the personality of the student in combination with demanding. All these principles are interconnected and mutually reinforcing. Special pedagogical conditions are the conditions necessary for the acquisition of knowledge and skills in particular subjects, taking into account the peculiarities of their teaching.

Based on the results of the study, it is concluded that in the second half of the twentieth century, the content of the practical purpose of teaching foreign language expanded from reading (translated and untranslated) in the 1950s to the formation of foreign language communicative competence in the 1990s. The target component varied according to the educational reforms and the requirements of the society as for foreign language proficiency of students of pedagogical educational establishments. The content of the educational aspect became a reflection of the ideology of public policy, which was enriched by other components only in the late 1980s (formation of the student's personality, increasing interest to the country which language was studied, patriotism and internationalism by means of foreign language). After Ukraine's declaration of independence, the role of national education and respect for the culture of other peoples and nationalities increased. These changes are reflected in the sociocultural competence of teaching foreign lan- guages in Ukrainian educational institutions. During this period, the teaching methods were developed on the basis of a person-centered approach [3] (Table 1).

An analysis of the development of teaching foreign languages in the second half of the twentieth century shows that the condition of complexity of teaching foreign languages began to be realized only in the 1990s according to the transformational processes in the content of Ukrainian education. It should be emphasized that the requirements for the subject "foreign language" in the pedagogical establishments of Ukraine of the studied period changed according to the revision of the goals of foreign language education, improvement of teaching methods and language policy of the state [8].

Therefore, pedagogical conditions are an integral element of the pedagogical system (holistic pedagogical process), they are a reflection of the totality of the educational environment. Pedagogical conditions of teaching foreign languages are organizational and pedagogical factors for the formation of foreign language communicative competence (linguistic, speech, sociocultural, national, linguistic and regional ones).

In today's Ukraine, the reform of education towards European integration is underway. The 2015-2020 Sustainable Development Strategy adopted in 2015 identifies foreign languages as a priority area for education reform. The document defines the task of increasing and optimizing Ukraine's presence at international events and venues, as well as its presence in the international academic, cultural and public environment. For its implementation, there is a need for a new level of teaching foreign language for young people in accor-

\section{Peculiarities of teaching foreign languages in secondary pedagogical educational establishments} of Ukraine in the second half of the XX th century

\begin{tabular}{|c|c|}
\hline Years & Features of foreign language training \\
\hline 1950s & $\begin{array}{l}\text { - over-theorizing of textbooks } \\
\text { - reading and translating text as the main types of activity in a foreign language class (practical goal) } \\
\text { - texts on military topics had the recommended character } \\
\text { - increasing attention to the educational influence of foreign language }\end{array}$ \\
\hline $1960 s$ & $\begin{array}{l}\text { - specification of practical purpose and recognition of its leading in relation to other purposes of foreign } \\
\text { language training } \\
\text { - definition of requirements for training of speech activities (reading, writing, speaking, listening) } \\
\text { - reducing the educational goal to ideological and political education } \\
\text { - expanding of the content to the general purpose }\end{array}$ \\
\hline 1970s & $\begin{array}{l}\text { - changing of the practical goal to communication or teaching foreign language communication } \\
\text { - general educational purpose is to use a foreign language as a means of communication } \\
\text { - educational purpose was to increase interest to the country which language was studied; development of } \\
\text { the personality of the student by means of a foreign language }\end{array}$ \\
\hline 1980s & $\begin{array}{l}\text { - reducing of the practical purpose to the formation of communicative competence and practical mastery } \\
\text { of a foreign language } \\
\text { - foreign language writing was considered as a means of better mastering of speaking and reading } \\
\text { - education of internationalism and patriotism as a component of educational purpose }\end{array}$ \\
\hline 1990s & $\begin{array}{l}\text { - strengthening of the national component } \\
\text { - development of Ukrainian textbooks based on the principle of variability } \\
\text { - transformation of the general purpose of teaching foreign languages to educational and developmental } \\
\text { purpose } \\
\text { - practical goal wasa formation of foreign language communicative competence (linguistic, speech, socio- } \\
\text { cultural and general). }\end{array}$ \\
\hline
\end{tabular}


dance with European standards. In addition, the Strategy states that 75 percent of graduates of education institutions will know at least two foreign languages, which will be confirmed by international certificates [5].

In 2015, the Go Global Program for the Study and Promotion of Foreign Languages was approved to change the language learning system in educational institutions with the support of the National Council of Reforms of Ukraine. The program identifies projects in four areas, namely: GoCamp (a new format of language school camps with the involvement of foreign volunteers), Global Goverment (an initiative to introduce compulsory foreign language skills in the civil service), Go Teaching (raising the level of language teaching in schools), Global Content is an activity aimed at promoting teaching foreign languages in Ukraine.Today in Ukraine there are changes in the system of teacher training of foreign languages, improvement of qualification of teachers, introduction of international standards of assessment of foreign language skills, implementation of new approaches and methods of teaching foreign languages [7].

The most effective in teaching foreign languages in modern educational institutions is competent and communicative approaches aimed at developing practical oral language skills.

Implementation of European approaches to teaching foreign languages at Ukrainian pedagogical educational institutions has been started, but there are a number of such disadvantages as low language proficiency of school graduates; a lack of intrinsic motivation for learning foreign languages; a lack of self-organization of students regarding the systematic language training; difficulty in mastering the language; insufficient hours of training; insufficient professional level of foreign language teachers. To enhance the qualification in Ukraine there are a lot of opportunities for the teachersto cooperate with international organizations such as British Council, US Peace Corps in Ukraine, Goethe Institute and others), as well as participation in online conferences, webinars, international projects and programs, trainings on foreign methodology were created. languages, etc.

Foreign language education in higher education institutions in non-linguistic specialties (where the foreign language is not a specialized language) reflects changes in the approaches and priorities of teaching foreign language for young people in search of the most effective methodology. The assertion that knowledge of a foreign language is an essential condition for the success and competitiveness of a modern specialist is well known, but we must recognize that the level and quality of teaching foreign languages in Ukraine does not respond for the current requirements of the European Community. Establishing economic, educational, political and cultural ties with other countries requires a restructuring of the existing methodology of teaching foreign languages in educational institutions. Ukraine's accession to the Bologna Process created the preconditions for the development of new curricula and textbooks (manuals) for the formation of a high level of foreign language competence of students.

Conclusions. The achievements of teachers and methodologists of foreign languages of the last century are important for preserving the continuity and possibility of influencing the educational processes of modern Ukraine for the development of a fully-developed, gifted, creative personality of the younger generation. The main priority of Ukraine's policy is European integration, which is the driving force for the development of economic, cultural and educational processes of our country. The purpose of the reforms is to create a national education system capable of providing a high level of training for foreign language specialists, preserving the past achievements, creating a new one in accordance with the state's capabilities and needs. However, there are contradictions between the importance of foreign language acquisition by Ukrainian citizens and the level of teaching foreign languages in secondary and higher educational institutions.

Thus, reforming Ukraine's foreign language education is important for the implementation of our country's educational processes. Positive changes and achievements of teachers-practitioners, scholars, linguists on the methods of teaching foreign languages in the educational institutions of Ukraine in the second half of the last century should become the basis for further reforming and improving of this direction of education in order to increase the efficiency of teaching foreign languages of students of modern educational institutions.

\section{БІБЛІОГРАФІЧНИЙ СПИСОК:}

1. Гушлевська І. Поняття компетентності у вітчизняній та зарубіжній педагогіці. Шлях освіти. 2004. № 3. С. 22-24.

2. Концепція викладання іноземних мов в Україні: проект. Інформаційний збірник Міністерства освіти України. 1994. № 24. С. 7-24.

3. Миролюбов А.А. История отечественной методики обучения иностранным языкам. Москва : СТУПЕНИ, ИНФРА-М, 2002. 448 с.

4. Основы методики преподавания иностранных языков / под ред. В.А. Бухбиндера и В. Штрауса. Киев : Вища школа, 1986. 335 с.

5. Стратегія сталого розвитку «Україна - 2020». URL: http://zakon1. rada. gov.ua/laws/show/5/2015.

6. Тадеєва М. Дидактико-методичні засади побудови концепції розвитку іншомовної освіти в Україні на 2011-2015 роки. Імідж сучасного педагога. 2011. № 4. C. 50-52.

7. Common European framework of reference for languages: learning, teaching, assessment. Language Policy Unit, Strasbourg. URL: https://www.coe.int/t/dg4/ linguistic/Source/Framework_EN.pdf.

8. Terletska L. Teaching foreign languages at pedagogical schools of Ukraine (the second half of XX century). Science and Education Studies. Stanford University Press, 2015. № 2 (16). Vol. III. P. 343-349. 